\title{
Ash Depression in Fine Coal Flotation Using a Novel Polymer Aid
}

\author{
Ontlametse Molatlhegi, Lana Alagha* \\ Department of Mining and Nuclear Engineering, Missouri University of Science and Technology, Rolla, USA \\ Email: ^alaghal@mst.edu
}

How to cite this paper: Molatlhegi, O. and Alagha, L. (2016) Ash Depression in Fine Coal Flotation Using a Novel Polymer Aid. International Journal of Clean Coal and Energy, 5, 65-85.

http://dx.doi.org/10.4236/ijcce.2016.54006

Received: September 30, 2016

Accepted: November 27, 2016

Published: November 30, 2016

Copyright $\odot 2016$ by authors and Scientific Research Publishing Inc. This work is licensed under the Creative Commons Attribution International License (CC BY 4.0).

http://creativecommons.org/licenses/by/4.0/

\begin{abstract}
The current study investigated the effects of novel hybrid polyacrylamide polymers as ash (slime) depressants in fine coal flotation to enhance combustible recovery and ash rejection. Coal samples at $\mathrm{P}_{80}$ of approximately 45 um with $\sim 25 \%$ ash content were floated in the presence of in-house synthesized hybrid aluminum hydroxide polyacrylamide polymers $\left(\mathrm{Al}(\mathrm{OH})_{3}-\mathrm{PAM}\right.$, or $\left.\mathrm{Al}-\mathrm{PAM}\right)$. All flotation experiments were carried out in a 5-L Denver flotation cell. Various influencing factors were examined to optimize the flotation process in the presence of the Al-PAM polymers, including the Al-PAM dosage, Al-PAM conditioning time, impeller rotation speed and pulp $\mathrm{pH}$. Comparative and synergistic studies were also performed using organic polyacrylamide polymers (PAMs), commercial dispersants and Al-PAM/dispersant system. Results showed a significant improvement in both combustible recovery and ash rejection at an Al-PAM dosage of $0.25 \mathrm{mg} / \mathrm{L}$. The maximum combustible recovery obtained, at natural $\mathrm{pH}$, with $\mathrm{Al}-\mathrm{PAM}$ and $\mathrm{Al}-\mathrm{PAM} /$ dispersant system was determined to be $70 \%$ and $66 \%$ at ash content of $7.74 \%$ and $7.4 \%$, respectively. Zeta potential values of both the raw coal and concentrate products showed a large shift toward more positive values (from $-50 \mathrm{mV}$ to $-13 \mathrm{mV}$ ), indicating a significant decrease in ash-forming minerals (slimes) when Al-PAM polymers were applied.
\end{abstract}

\section{Keywords}

Fine Coal Flotation, Novel Organic/Inorganic (Hybrid) Polyacrylamide, Zeta Potential, Slime Coating

\section{Introduction}

The effective liberation of coal particles from lower-grade coal deposits requires micron and submicron comminution processes that will generate a vast amount of coal fines. A large amount of coal fines and ultrafines can also be generated due to the adoption of 
modern full seam mechanized mining, ore handling and preparations [1]. These produced coal fines and ultrafines contain an enormous amount of colloidal-sized, ashforming minerals due to the admixture of clay minerals and other impurities that would likely disseminate to fine and ultrafine fractions. In the past, coal fines from the mines were discarded or stored in refuse ponds. According to a study conducted by the National Research Center, over 70 - 90 million tons of coal fines were annually deposited in refuse ponds in the USA [2]. The fine coal refuse is said to be environmentally harmful, leaching toxins into rivers and streams. The rise of stricter environmental regulations to minimize the pollution of land and water has hastened the need for the cleaning and recovery of discarded coal fines particles. Additionally, improving coal prices and technology have made the recovery of coal fines more viable, as they represent a notable economic resource base. At present, conventional froth flotation is the only commercially available method for the cleaning and recovering of coal fines [3]. The process utilizes differences in surface wettability between coal particles and ash-forming inorganic matter. However, the coal flotation process has been challenging, problematic and costly due to the slime coating of colloidal mineral matter on the surfaces of coal particles and air bubbles. These slime coatings likely reduce the effectiveness of flotation recovery, especially when fine grinding is required. Slimes inhibit bubble-particle attachment and increase reagent consumption due to an increased sol$\mathrm{id} /$ liquid interfacial area, resulting in low coal recovery.

Synthetic and naturally occurring polymers have been successfully used in mineral processing/coal preparation mainly as gangue depressants or dispersants to increase the combustible recovery of coal fines [4]-[10]. Reza et al. proposed selective flotation using sodium polyacrylic acid and polyacrylamides. In this method, polymers were added to the flotation pulp to selectively flocculate the ash-forming minerals [11]. The results showed that sodium polyacrylic acid improved the recovery but did not enhance the reduction of sulfur and ash, whereas polyacrylamide completely depressed the coal and hence reduced the overall recovery. Raleigh and Aplan reported that the dual use of mineral dispersants and polymeric depressants improved the overall coal flotation recovery and ash reduction by rejecting partially locked or coal-free gangue that were accidentally trapped in the froth layer [12]. Several investigators have also demonstrated that the use of tri-block copolymers of polyethylene oxide (PEO) and polypropylene oxide (PPO) as flotation collectors could increase the hydrophobicity of coal and significantly increase the overall recovery. However, these polymeric surfactants were unable to reduce the ash content [7]. There is no literature available on the use of $\mathrm{Al}(\mathrm{OH})_{3}$-PAM (Al-PAM) hybrid polymers in coal flotation. However, Li et al. investigated the effects of an Al-PAM hybrid polymer on the recovery of bitumen during the flotation of oil sands [13]. In that study, $\mathrm{Al}(\mathrm{OH})_{3}-\mathrm{PAM}$ and partially hydrolyzed anionic PAM (Magnafloc 1011) were used either separately or together. The results showed that the use $\mathrm{Al}(\mathrm{OH})_{3}$-PAM alone led to a decrease in bitumen recovery due to the formation of large bitumen lumps during froth flotation. However, holistic improvements in bitumen recovery, froth quality and tailings settling were achieved when $\mathrm{Al}(\mathrm{OH})_{3^{-}}$ 
PAM was used in combination with Magnafloc 1011 at a low dosage. In the current work, a novel organic-inorganic hybrid polyacrylamide polymer, Al-PAM, was synthesized and used for the selective depression of ash-forming mineral matter in fine coal flotation. The influence of polymer dosage, polymer conditioning time, pulp $\mathrm{pH}$ and impeller speed were investigated. The effect of commercially available polyacrylamide (PAM) polymer and sodium metasilicate dispersant on the flotation process were also examined for comparison.

\section{Experimental Section}

\subsection{Materials}

Coal samples used in this study were obtained from a mine located in Southern Illinois, USA. The as-received run-of-the-mine coal was first crushed in a jaw crusher $(2 \times 6$ model, Sturtevant Inc., Hanover, MA, USA) and then further crushed in a roll crusher $(8 \times 5$ model Sturtevant Inc., Hanover, MA, USA $)$ to a size of $850 \mu \mathrm{m}$. Finally, a laboratory ball mill was used to grind the coal samples to a finer size. After crushing and grinding, the coal was screened to $-75,+38 \mu \mathrm{m}$ to be used as a feed in all flotation experiments. The particle size distribution of the flotation feed showed a $\mathrm{P}_{80}$ value of 45 um. The proximate analysis of the $-75,+38 \mu \mathrm{m}$ coal (flotation feed) is shown in Table 1. Proximate analysis was conducted as per ASTM D3172-13 standards. All chemicals used in the flotation experiments were purchased from Fisher Scientific (USA). This includes kerosene, which was used as a coal collector; methyl isobutyl carbinol (MIBC), which was used as a frothing agent; sodium metasilicate, which was used as a dispersant in synergistic studies; and polyacrylamide polymer, which was used in comparative studies. Sodium hydroxide $(\mathrm{NaOH})$ and hydrochloric acid $(\mathrm{HCl})$ were used to adjust the $\mathrm{pH}$ of the flotation pulp and were also purchased from Fisher Scientific (USA).

\subsection{Synthesis of $\mathrm{Al}(\mathrm{OH})_{3}$-Polyacrylamide (Al-PAM)}

The hybrid polyacrylamide Al-PAM was synthesized in-house according to a procedure described elsewhere [14]. Al-PAM was synthesized by the polymerization of acrylamide monomers in an $\mathrm{Al}(\mathrm{OH})_{3}$ colloidal suspension using $\left(\mathrm{NH}_{4}\right)_{2} \mathrm{~S}_{2} \mathrm{O}_{8} / \mathrm{NaHSO}_{3}$ as a redox initiator. To prepare the $\mathrm{Al}(\mathrm{OH})_{3}$ colloid, approximately $0.33 \mathrm{~g}$ of anhydrous aluminumchloride $\left(\mathrm{AlCl}_{3},>99 \%\right)$ were dissolved in distilled water to make $25 \mathrm{~g}$ of a $0.01 \mathrm{M}$ $\mathrm{AlCl}_{3}$ solution. Approximately $0.48 \mathrm{~g}$ of ammonium carbonate $\left(\left(\mathrm{NH}_{4}\right)_{2} \mathrm{CO}_{3}\right)$ were dissolved in distilled water in a different beaker to make $50 \mathrm{~g}$ of $0.1 \mathrm{M}\left(\mathrm{NH}_{4}\right)_{2} \mathrm{CO}_{3}$. A Master FLEX mini pump was used to gradually add the $\left(\mathrm{NH}_{4}\right)_{2} \mathrm{CO}_{3}$ solution to the $\mathrm{AlCl}_{3}$

Table 1. Proximate analysis of coal sample used as a flotation feed ( $\left.-75 \mathrm{um}, \mathrm{P}_{80} \sim 45 \mathrm{um}\right)$.

\begin{tabular}{cc}
\hline Proximate Analysis & As determined (\%) \\
\hline Moisture & 10.05 \\
Ash & 25.12 \\
Volatile matter & 22.94 \\
Fixed carbon & 44.86 \\
\hline
\end{tabular}


solution at a rate of $0.5 \mathrm{~g} / \mathrm{min}$. After adding approximately $36-37 \mathrm{~g}$ of the $\left(\mathrm{NH}_{4}\right)_{2} \mathrm{CO}_{3}$ solution into $25 \mathrm{~g}$ of $\mathrm{AlCl}_{3}$ solution, the pump was stopped and the solution was gently stirred at a rate of $300 \mathrm{rpm}$ for approximately $30 \mathrm{~min}$ to complete the reaction. The prepared $\mathrm{Al}(\mathrm{OH})_{3}$ suspension has an approximate particle size of $30-50 \mathrm{~nm}$, and the measured zeta potential value was $+27,-30 \mathrm{mV}$. The particle size and zeta potential studies were measured using a Zetasizer Nano ZS (Malvern, USA) The next step was the polymerization of acrylamide in an $\mathrm{Al}(\mathrm{OH})_{3}$ colloidal suspension to synthesize the Al-PAM polymer. The polymerization process was achieved according to the following procedure: approximately $4.5 \mathrm{~g}$ of acrylamide monomer was dissolved in $25.5 \mathrm{~mL}$ of previously prepared $\mathrm{Al}(\mathrm{OH})_{3}$ colloidal suspensions. The suspension was stirred and heated in an oil bath to $40^{\circ} \mathrm{C}$ under nitrogen flow for nearly $30 \mathrm{~min}$. Two milliliters of $1000 \mathrm{mg} / \mathrm{L}$ stock solutions of redox initiators $(1 \mathrm{~mL}$ each) were slowly added to the prepared $\mathrm{Al}(\mathrm{OH})_{3}$ suspension containing acrylamide monomer to initiate the polymerization of acrylamide onto colloidal aluminum hydroxide particles. The polymerization reaction was kept running overnight. The formed Al-PAM gel was dissolved in MilliQ water to $10 \mathrm{wt} \%$. The aqueous polymer colloidal suspension was then introduced into acetone drop-wise to precipitate Al-PAM. The resulting solid precipitates were dried under vacuum at $55^{\circ} \mathrm{C}$ for $6-8$ hours. Freshly prepared $1000 \mathrm{mg} / \mathrm{L}$ stock solutions of Al-PAM polymers in deionized water were used in all of the flotation experiments.

\section{Polymer Characterization}

The aluminum content by weight in Al-PAM polymer was measured using the PerkinElmer Inductively coupled plasma system 2000 DV instrument equipped with Optical Emission Spectrophotometer and WinLab32 for ICP version software for measurement of Aluminum at wavelength $396.153 \mathrm{~nm}$. The RF power was used 1500 watts, Plasma flow was $15 \mathrm{~L} / \mathrm{min}$, Auxiliary Flow was kept at $0.2 \mathrm{~L} / \mathrm{min}$, and Nebulizer Flow was kept at $0.8 \mathrm{~L} / \mathrm{min}$, Pump Rate was kept at $2 \mathrm{ml} / \mathrm{min}$. The calibration curve plotted using 7 different concentrations of solutions diluted in $1 \% \mathrm{HNO}_{3}(0 \mathrm{mg} / \mathrm{L}, 0.1 \mathrm{mg} / \mathrm{L}, 0.5 \mathrm{mg} / \mathrm{L}$, $1 \mathrm{mg} / \mathrm{L}, 5 \mathrm{mg} / \mathrm{L}, 10 \mathrm{mg} / \mathrm{L}$, and $25 \mathrm{mg} / \mathrm{L}$ ) made by using HIGH-PURITY STANDARDS purchased from Fisher-Scientific. The correlation coefficient was 0.9999. Sample measurements were repeated in 3 times. The sample contains $0.14 \mathrm{wt} \%$ of aluminum.

Molecular weight of Al-PAM was determined using a Zetasizer Nano (Malvern Instruments Ltd., USA) by employing static light scattering (SLS). Zetasizer Nano software measures the intensities of the scattered light of the polymer sample and automatically calculates the molecular weight by applying the Rayleigh Equation (1) below [15].

$$
\frac{K C}{R \theta}=\left(\frac{1}{M_{W}}+2 A_{2} C\right) P(\theta)
$$

where $R \theta$ is Rayleigh ratio which is the ratio of scattered light to incident light; $M_{W}$ is the molecular weight; $A_{2}$ is the $2^{\text {nd }}$ Virial Coefficient which represents the interaction strength among the polymer chains and has been correlated with solubility [16]; $C$ is the concentration of polymer solution; $P(\theta)$ is the angular dependence of the sample 
scattering intensity and $K$ is the optical constant as defined below in Equation (2).

$$
K=\frac{4 \pi^{2}}{\lambda_{O}^{4} N_{A}}\left(n_{o} \frac{\mathrm{d} n}{\mathrm{~d} c}\right)^{2}
$$

where $N_{A}$ is Avogadro's constant; $\lambda_{o}$ is the wavelength of laser used; $n_{o}$ is the refractive index of the solvent and $\mathrm{d} n / \mathrm{d} c$ is the differential refractive index increment which is the change in refractive index as a function of the change in concentration. Therefore, a plot of $K C / R \theta$ versus $C$ is expected to be linear with an intercept equivalent to $1 / M_{W}$ and a slope equal to the second virial coefficient $A_{2}$. This plot is known as "Debye plot". To establish Debye plot of Al-PAM, samples of different concentration; 15, 13.5, 10.5 and $7.5 \mathrm{mg} / \mathrm{ml}$ were prepared. The calibration was made by using pure $(>99.5 \%)$ toluene. All measurements were conducted at $25^{\circ} \mathrm{C}$. The Debye plot for the Al-PAM data is shown in Figure 1, which indicates a molecular weight of $6.180 \times 10^{6} \mathrm{Da}$ and a $2 \mathrm{nd}$ virial coefficient of $0.000126 \mathrm{ml} \cdot \mathrm{mol} / \mathrm{g}^{2}$.

\subsection{X-Ray Diffraction (XRD) Analysis}

An XRD analysis was used to reveal qualitative information on the mineral composition of raw coal samples $(-75 \mu \mathrm{m}+35 \mu \mathrm{m})$ used in this study. The XRD analysis was performed using a PANalytical X'Pert Pro Multi-Purpose Diffractometer (MPD; PANalytical, Inc., MA, USA) system with a $\mathrm{Cu}$ (k-alpha)-source at a tube voltage of $40 \mathrm{kV}$. Table 2 and Figure 2 show the quantitative and qualitative analyses, respectively, of the mineral matter composition in the coal samples obtained from the XRD analysis. The proportion of amorphous material to crystalline material in the coal sample was determined to be $76.2 \%$ by weight, which is in a good agreement with ash contents determined

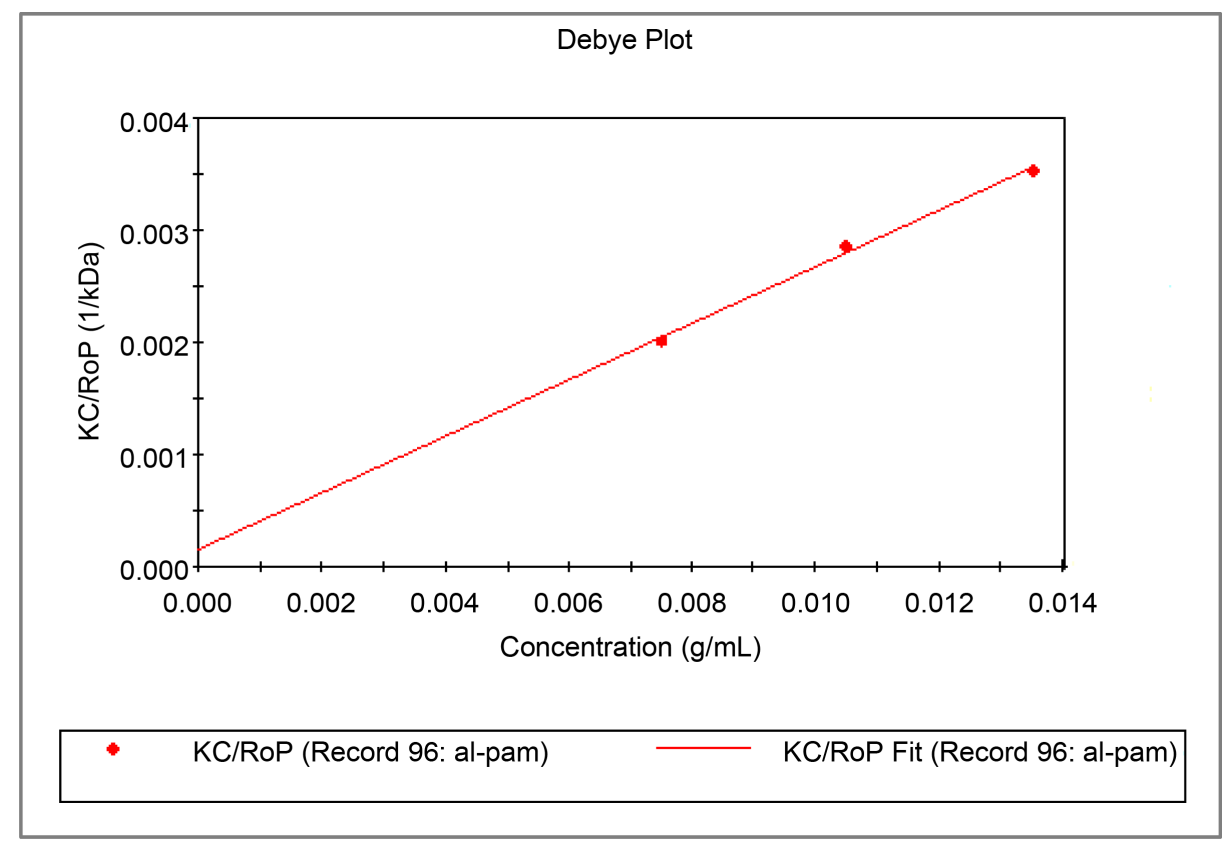

Figure 1. Debye plot generated by zetasizer nano ZS software to determine the molecular weight of Al-PAM polymer used as ash depressant. 
Table 2. Quantitative results scaled to the internal standard for the coal sample used as flotation feed ( $-75 \mathrm{um}, \mathrm{P}_{80} \sim 45 \mathrm{um}$ ).

\begin{tabular}{cc}
\hline Content & Wt.(\%) \\
\hline Amorphous & 76.2 \\
$\mathrm{FeS}_{2}$ (Pyrite) & 1.0 \\
Quartz & 5.9 \\
Kaolinite $\mathrm{Al}_{2}\left(\mathrm{Si}_{2} \mathrm{O}_{5}\right)(\mathrm{OH})_{4}$ & 4.6 \\
Corundum, $\mathrm{Al}_{2} \mathrm{O}_{3}$ & 10.2 \\
Calcite, $\mathrm{Ca}\left(\mathrm{CO}_{3}\right)$ & 2.1 \\
\hline
\end{tabular}

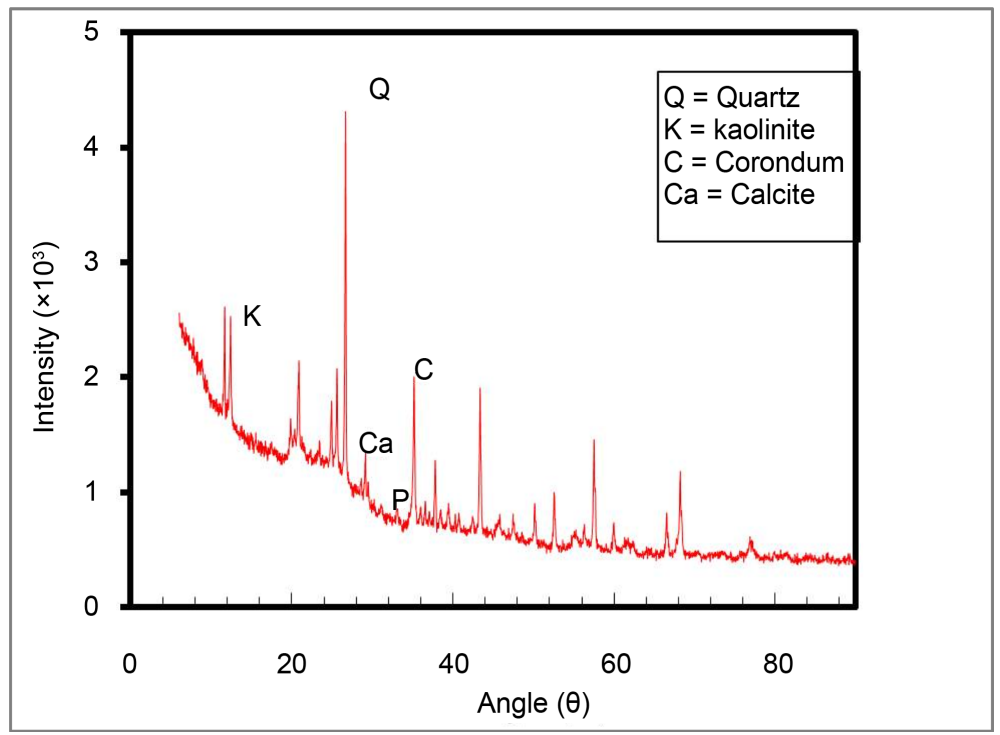

Figure 2. XRD analysis spectra for the flotation feed ( $-75 \mathrm{um}, \mathrm{P}_{80} \sim 45 \mathrm{um}$ ).

by proximate analysis. The major crystalline phases observed were $\mathrm{FeS}_{2}$ (pyrite), quartz, kaolinite $\mathrm{Al}_{2}\left(\mathrm{Si}_{2} \mathrm{O}_{5}\right)(\mathrm{OH})_{4}$, corundum $\mathrm{Al}_{2} \mathrm{O}_{3}$ and small amounts of calcite $\mathrm{Ca}\left(\mathrm{CO}_{3}\right)$.

\subsection{Release Analysis (RA)}

An RA is the analogous counterpart in coal froth flotation to the float and sink methods in coal gravity concentration. The major objective of an RA is to obtain the best possible separation performance by any froth flotation process [17]. The flotation RA was carried out in a conventional laboratory flotation cell. Figure 3 shows the timed RA result for a coal flotation feed sample: combustible recovery vs. product ash. At a product ash content of $8.2 \%$, the combustible recovery of coal is approximately $58 \%-59 \%$. The timed RA data indicated that the coal sample used in this study had poor floatability and that further cleaning of this coal sample to produce a product ash of $5 \%-6 \%$ would be difficult. The combustible recovery of coal decreases sharply as the ash products decreases to less than $6 \%$. RA was also used to obtain a clean coal product $(<4 \%$ ash) for comparative zeta potential measurements. 


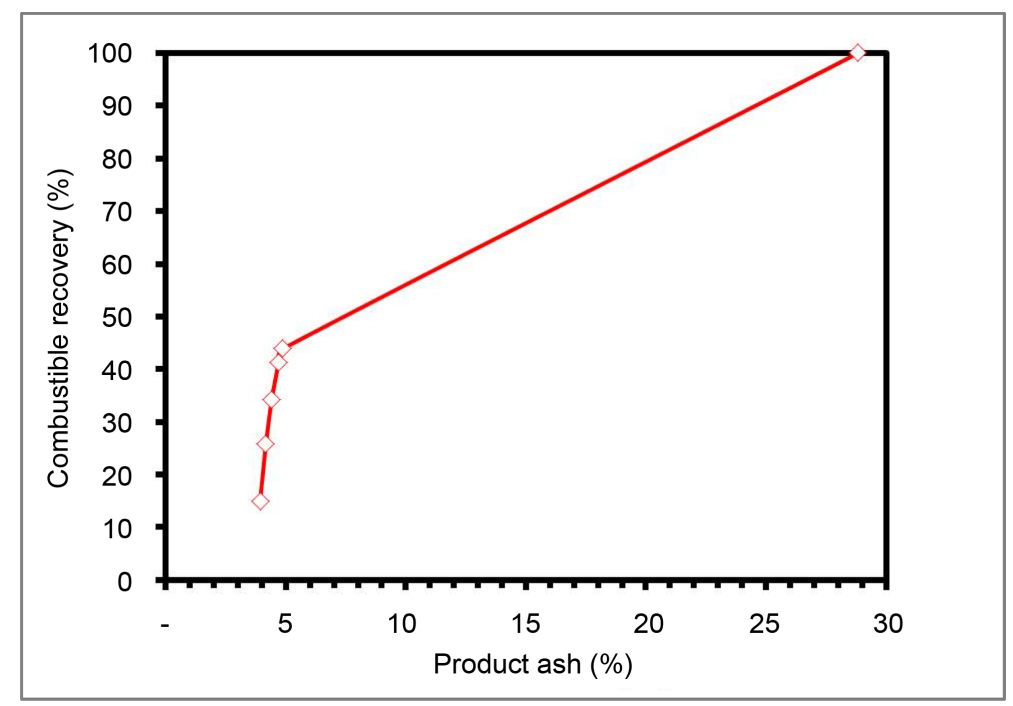

Figure 3. Timed release analysis result showing combustible recovery vs product ash for the feed sample ( $\left.-75 \mathrm{um}, \mathrm{P}_{80} \sim 45 \mathrm{um}\right)$.

\subsection{Zeta Potential Measurements}

The zeta potential of the coal samples were measured using a Zetasizer Nano ZS instrument (Malvern Instruments, Inc., Westborough, MA, USA). Data on the interactions of coal samples with ash-forming minerals in the flotation pulp were obtained by measuring the zeta potential of the raw coal samples and the froth obtained from the polymer-assisted flotation process and comparing the results to the zeta potential of clean coal obtained from the RA. The experiments were conducted using a $0.01 \mathrm{M} \mathrm{KCI}$ electrolyte solution at natural $\mathrm{pH}$. Zeta potential measurements were performed for raw coal (i.e., the flotation feed), the first concentrate produced from the RA (herein referred to as clean coal with an ash content of 3.91\%) and froth collected from the polymer-assisted flotation. Sample measurements were repeated 3 times. Isoelectric graphs of the clean and raw coal were obtained using MPT-2 autotitrator which is part of the Zetasizer Nano. The solution $\mathrm{pH}$ was adjusted using $\mathrm{HCl}$ and $\mathrm{NaOH}$. Coal suspensions were prepared at $1 \mathrm{wt} . \%$ coal in a $0.01 \mathrm{M} \mathrm{KCI}$ solution. Each prepared coal suspension was agitated using an IKA RW 20 mechanical stirrer for approximately $30 \mathrm{~min}$ at a constant agitation rate of $300 \mathrm{rpm}$. The suspension was then allowed to settle for $5-10$ min. The upper portion of the supernatant was considered for the zeta potential distribution measurements.

\subsection{Batch Flotation Tests}

Batch flotation experiments were conducted to study the effects of novel organic/inorganic (hybrid) polyacrylamide polymers in enhancing the combustible recovery and ash rejection of coal flotation under various operating parameters. All flotation experiments were conducted 3 times as indicated by the error bars in the figures. In the study, various parameters, such as polymer dosage, impeller speed, $\mathrm{pH}$ and conditioning time, were assessed individually. All of the flotation experiments were run in a $5-\mathrm{L}$ 
D12-Denver flotation laboratory cell at natural $\mathrm{pH}$ unless otherwise stated. The air flow rate and solids concentration were kept constant at $6 \mathrm{~L} \mathrm{pm}$ and 5\%, respectively, in all experiments. In a typical flotation test, $253 \mathrm{~g}$ of coal and $4800 \mathrm{~mL}$ of tap water were loaded in the 5-L cell, and the pulp was conditioned to allow wetting of the coal for 5 min prior to any reagent addition. Collector (i.e., kerosene) was then added at a predetermined dosage, and the suspension was conditioned for an additional $3 \mathrm{~min}$. A desired dosage of Al-PAM was added after the slurry was conditioned with the collector, and the pulp was agitated for another $3 \mathrm{~min}$. When the dispersant was used, it was first added before adding the collector. The polymer and dispersant dosages are expressed in reference to the total volume of the feed slurry (i.e., the combined volume of coal and water). The frothing agent (MIBC) was added at a fixed amount of $200 \mu \mathrm{L} /$ ton on a mass basis relative to the dry feed mass. The pulp was further conditioned for $2 \mathrm{~min}$ before air was introduced. The resultant froth was collected at 1-min time intervals. The concentrate fractions were washed, filtered and dried in an oven overnight at $80^{\circ} \mathrm{C}$. After drying, the ash contents of the concentrates were determined according to ASTM D3174-73 [18].

\subsection{Kinetic Tests}

Flotation kinetic tests were conducted to determine the effects of Al-PAM on the flotation rate constants. All experiments were conducted in the presence or absence of $\mathrm{Al}-\mathrm{PAM}$ at the optimum dosages for comparison purposes. In each test, the froth product was collected at 1-min time intervals; 5 fractions were collected. The collected fractions were washed, filtered and dried in an oven overnight at $80^{\circ} \mathrm{C}$. After drying, the ash contents of the concentrates were determined according to ASTM D3174-73.

\section{Results and Discussion}

\subsection{Studies on Al-PAM}

\subsubsection{Influence of Al-PAM Dosage}

A series of flotation experiments were conducted to determine the effects of Al-PAM at various dosages (i.e., $0.04,0.08,0.16,0.25,0.5,1,2$, and $3 \mathrm{mg} / \mathrm{L}$ ) on the combustible recovery of coal and product ash. In this set of experiments, a collector, Al-PAM polymer and a frothing agent were sequentially added to coal slurries. Baseline experiments without the Al-PAM polymer were performed periodically to define a base recovery and product ash vs. dosage relationship to ensure the reproducibility of the results and a congruity of the experiment parameters. As shown in Figure 4, the use of Al-PAM increased the overall combustible recovery of coal by $7.2 \%$. This increase in combustible recovery was observed for the Al-PAM dosage range of $0.04-0.25 \mathrm{mg} / \mathrm{L}$. The increased combustible recovery was anticipated to the electrostatic adsorption of positively charged $\mathrm{Al}(\mathrm{OH})_{3}$ particles on the surfaces of negatively charged ash particles (mainly clay slimes) and the consequent decrease of electrostatic repulsion between the ash-forming mineral particles. As a result, ash-forming mineral particles are able to form aggregates by allowing the arms (branches) of PAM polymers to bind, leading to 
particulate settling in the tailing stream. The proposed mechanism of depression of ash-forming minerals by Al-PAM polymer in fine coal flotation is depicted in Figure 5. The product ash content decreased slightly from $8.2 \%$ (no polymer added) to $7.9 \%$ when $0.25 \mathrm{mg} / \mathrm{L}$ of Al-PAM was added. An increased dosage of Al-PAM from 0.5 to 3 $\mathrm{mg} / \mathrm{L}$ resulted in an overall decrease in the combustible recovery of coal from $66.85 \%$ to $43.3 \%$, possibly due to the homo- or hetero-coagulation of coal particles by polymer molecules when excess polymer was added. The coagulation of coal by Al-PAM was driven by the physical adsorption of the polymer molecules on the surface of coal particles. This physical adsorption could be attributed to short-range electrostatic attractive

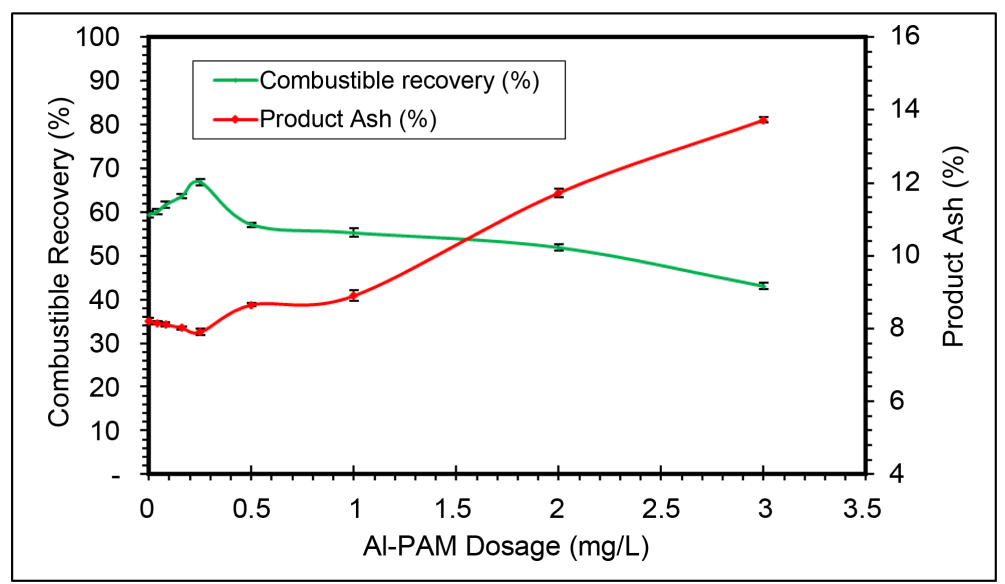

Figure 4. Influence of Al-PAM dosage on the combustible recovery (\%) of coal and product ash (\%).

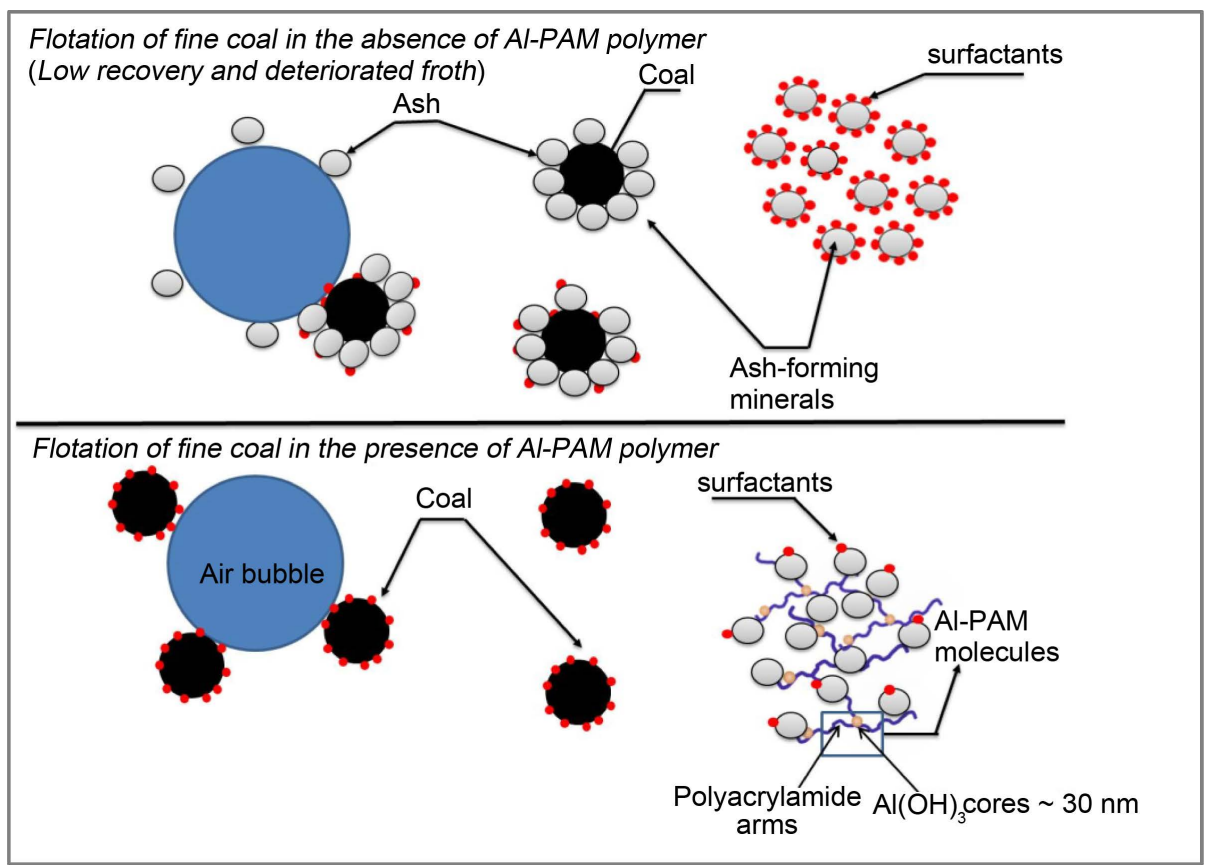

Figure 5. Proposed mechanism of depression of ash-forming minerals by Al-PAM polymer chains. 
forces and/or hydrogen bonding. Coagulation would result in the settling of coal particles and thereby decrease the recovery. Additionally, the product ash content also increased from $7.9 \%$ to $13.7 \%$ as the Al-PAM dosage increased from 0.5 to $3 \mathrm{mg} / \mathrm{L}$.

\subsubsection{Influence of Impeller Speed}

To better understand the effect of hydrodynamics on the flotation performance, coal flotation experiments were carried out at various impeller speeds (i.e., 1200, 1500, 1800 and $2100 \mathrm{rpm}$ ) in the presence or absence of Al-PAM polymers. First, a set of baseline flotation experiments were conducted without Al-PAM. Figure 6(a) and Figure 6(b) show the effects of the impeller rotational speed on the clean coal combustible recovery and product ash in the absence or presence of Al-PAM. As shown in Figure 6(a), the combustible recovery of coal increased with increasing impeller speed in the absence or presence of Al-PAM. However, this increase was greater with Al-PAM than without Al-PAM. This increased combustible recovery was due to the increased amount of energy being introduced into the cell system by impeller agitation. At higher agitation speeds, the momentum of coal particles increased and improved the collision probabilities with air bubbles. In the case of product ash, Figure 6(b) shows that in the presence of $0.25 \mathrm{mg} / \mathrm{L}$ of Al-PAM, lower product ash content was observed at lower impeller rotational speeds and a higher product ash content was observed at higher impeller speeds. The optimum impeller rotation speed was found to be $1800 \mathrm{rpm}$ with the lowest product ash of $7.9 \%$ and a combustible recovery rate of $66.85 \%$. This optimum value was similar to that obtained when no polymer was added. The fact that the addition of Al-PAM to the flotation pulp increased the overall combustible recovery and slightly decreased the product ash (significantly at $1800 \mathrm{rpm}$ ) illustrates that the presence of Al-PAM considerably improved the flotation efficiency.

\subsubsection{Influence of Polymer Conditioning Time}

Reagent conditioning plays a dominant role in the overall performance of the flotation process and has been recognized as an important method for improving the performance of the flotation process. Kalyani et al. concluded that reagent conditioning
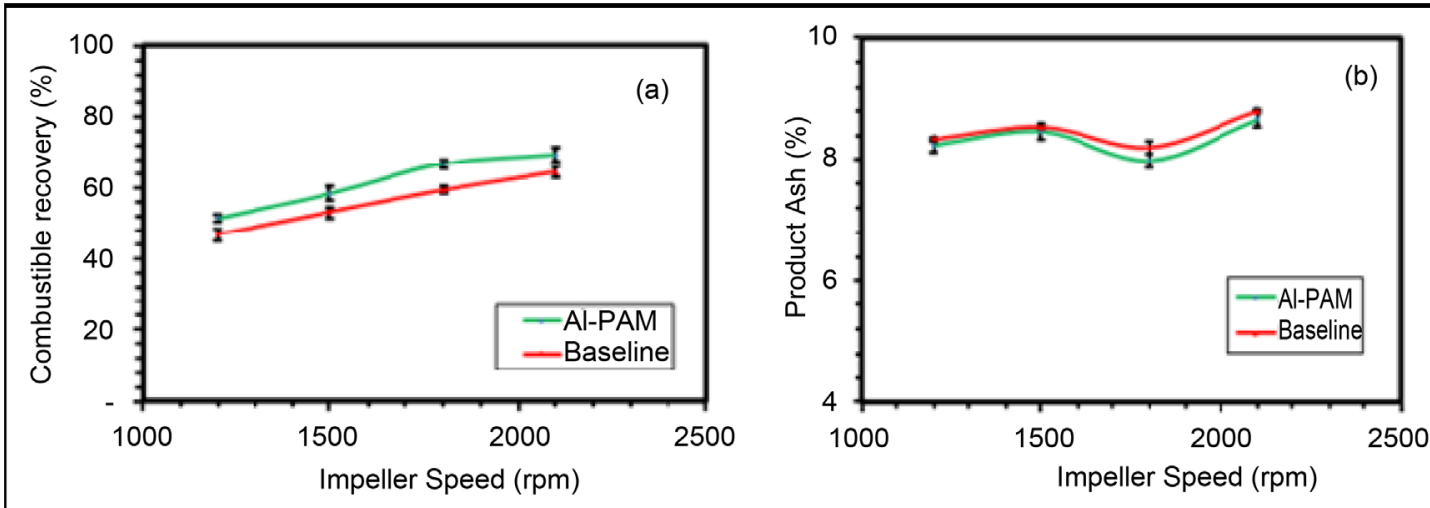

Figure 6. Effect of impeller speed on (a) combustible recovery and (b) product ash in the presence and absence of Al-PAM. 
enables regents to be uniformly distributed within the suspension and thereby improves the collision and adhesion probability of distributed reagents with coal particles [19]. In this set of experiments, the polymer dosage, impeller speed and $\mathrm{pH}$ were kept constant at $0.25 \mathrm{mg} / \mathrm{L}, 1800 \mathrm{rpm}$ and 7.8 , respectively. The polymer conditioning time was varied at $0,3,6$ and $9 \mathrm{~min}$. The results of the combustible recovery and product ash of coal as a function of polymer conditioning time are shown in Figure 7. The combustible recovery of coal initially increased with increasing conditioning time until a maximum was reached at $3 \mathrm{~min}$. The combustible recovery was $59.47 \%$ before conditioning and increased to $66.85 \%$ after $3 \mathrm{~min}$ of conditioning time. The combustible recovery decreased slightly to $65.92 \%$ and $62.97 \%$ as the polymer conditioning time further extended to 6 and $9 \mathrm{~min}$, respectively. The results also showed that a cleaner coal product with lower ash content was obtained as the polymer conditioning time increased. The optimum conditioning time was found to be at $6 \mathrm{~min}$, at which a combustible recovery of $65.92 \%$ and a product ash of $7.74 \%$ were observed.

\subsubsection{Influence of $\mathrm{pH}$}

Solution $\mathrm{pH}$ is one of the most important factors controlling slime coating due to the possible Van Der Waals attractive forces between ash-forming minerals and coal particles. Flotation experiments were conducted at a slightly acidic $\mathrm{pH}$ of 5 and a moderately alkaline $\mathrm{pH}$ of 10.2 to further explore the role of Al-PAM in coal flotation. First, baseline flotation experiments (collector and frothing agents only) were conducted at $\mathrm{pH}$ values of 5, 7.8 and 10. Figure 8(a) and Figure 8(b) show the effect of $\mathrm{pH}$ on clean coal combustible recovery and product ash in the absence or presence of Al-PAM, respectively. As shown in Figure 6(a), in the absence of Al-PAM (baseline experiments), the maximum clean coal combustible recovery of $70.48 \%$ occurs at a slightly acidic $\mathrm{pH}$ of 5 compared with $59.47 \%$ at $\mathrm{pH} 7.8$ and $40.83 \%$ at $\mathrm{pH} 10.2$. The results correlate well with the zeta potential measurement conducted in this study (Figure 9). A number of studies in the literature have also reported that coal is more floatable under conditions

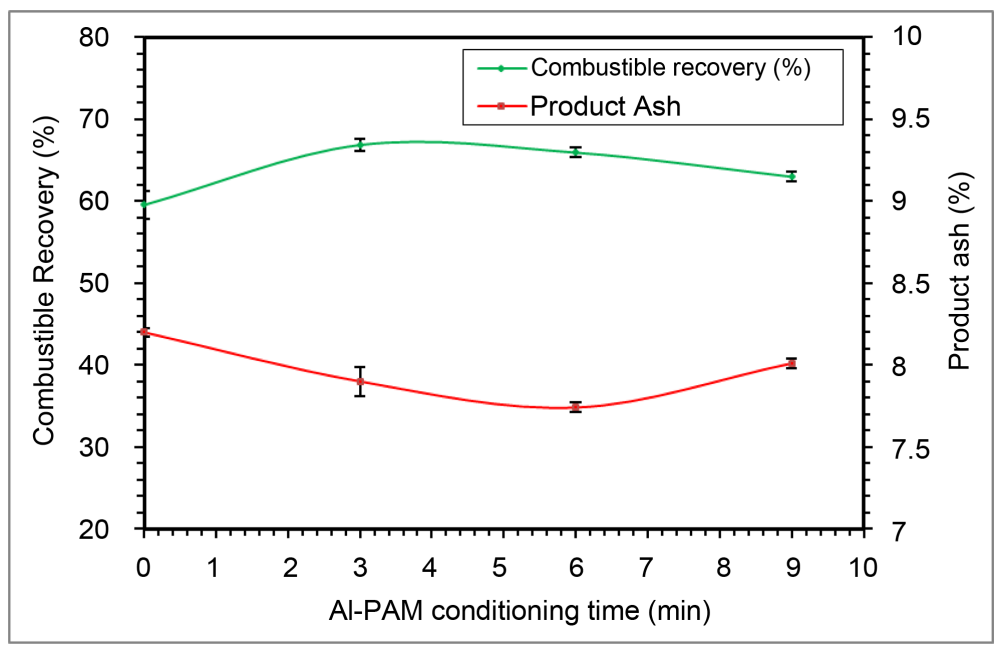

Figure 7. Effects of Al-PAM conditioning time on the combustible recovery (\%) of coal and product ash (\%). 


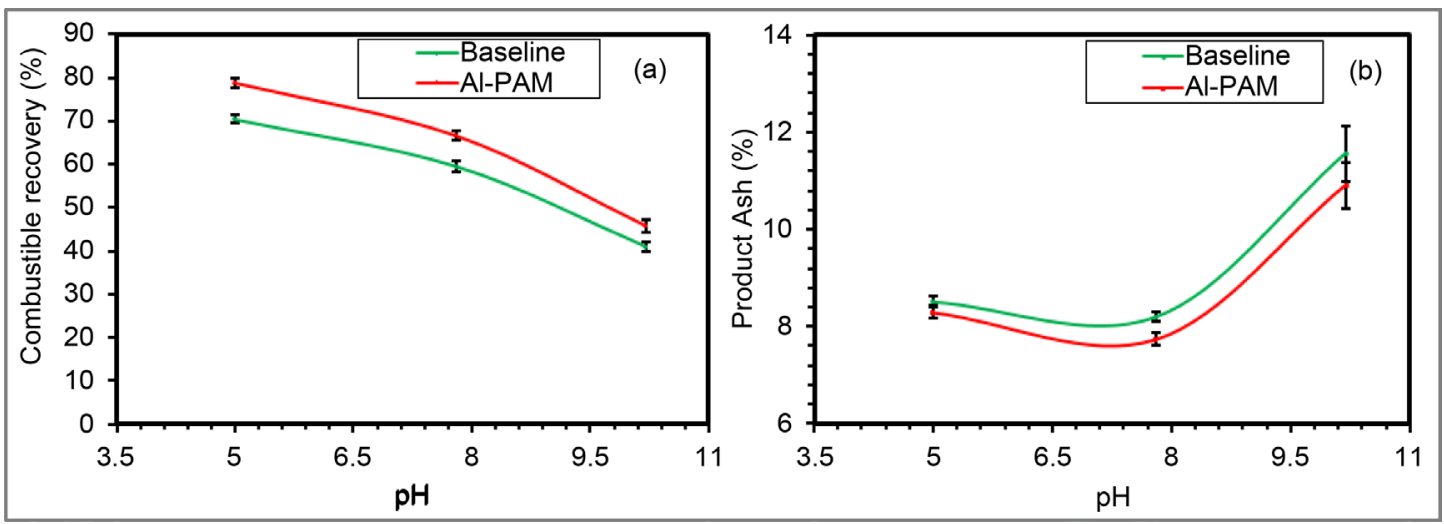

Figure 8. Effect of $\mathrm{pH}$ on combustible recovery (a) and product ash (b) in the presence and absence of Al-PAM.

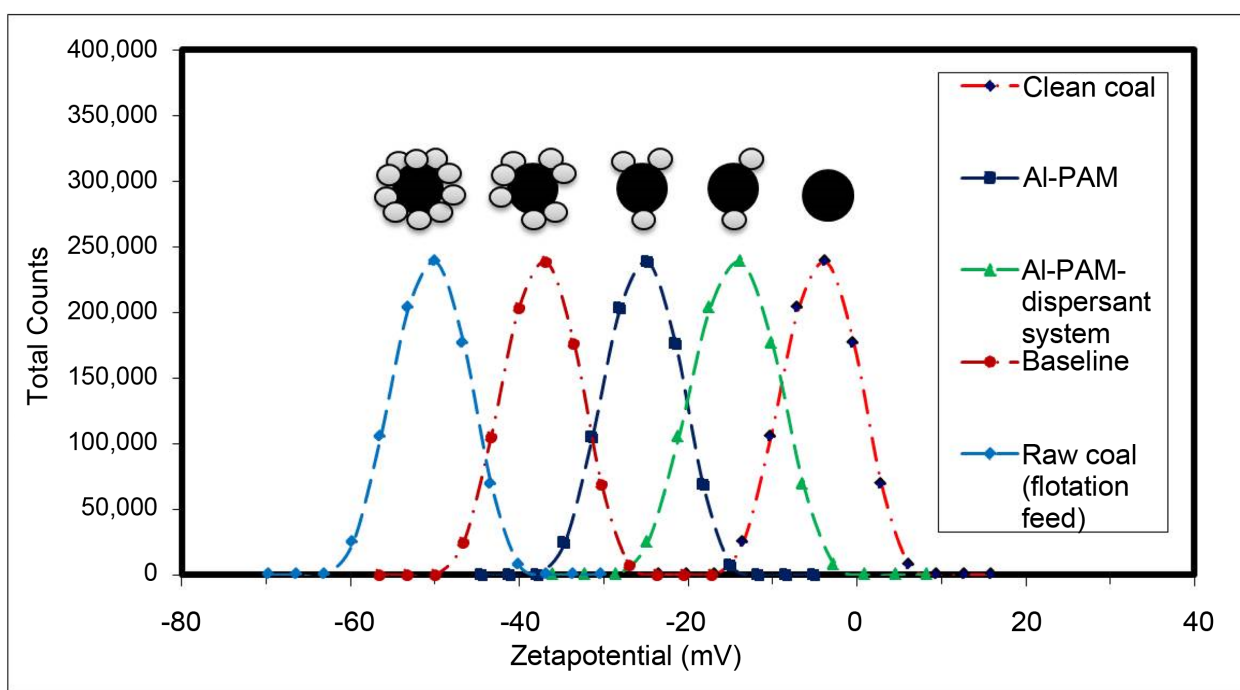

Figure 9. Zeta potential distribution peaks for clean coal (4\% ash), raw coal, concentrates obtained from froth flotation experiments using Al-PAM, the dual Al-PAM-dispersant system and in the absence of both Al-PAM-dispersant (baseline). Black and gray circles represent coal and mineral matter (slime coating) particles, respectively.

closer to its isoelectric points, i.e., at pH 3 - 5 [20] [21]. As is further shown in the Figure 8(a), the combustible recovery of coal decreased at an alkaline $\mathrm{pH}$ of 10.2. At this relatively higher $\mathrm{pH}$, the surface charge on coal particles will be more negative and this will increase the possible adsorption or precipitation of positively charged metal ions from solution and decreased flotation. The influence of $\mathrm{pH}$ on clean coal combustible recovery in the presence of Al-PAM alone was similar to the trend observed for the baseline experiments. However, the addition of Al-PAM increased the combustible recovery of coal from $70.48 \%$ (baseline experiments) to $78 \%$ at $\mathrm{pH} 5$. A weakly acidic pulp $\mathrm{pH}$ of 5 likely made the coal surface slightly less electronegative, which in turn would decrease the competitive adsorption of polymer on coal particles and increase the selectivity of polymer adsorption on ash particles. Thus, a higher floatability and combustible recovery is achieved. As shown in Figure 8(b), in the absence of Al-PAM, product ashes of $8.5 \%, 8.2 \%$ and $11.56 \%$ were obtained at $\mathrm{pH} 5,7.8$ and 10.2 , respec- 
tively. With Al-PAM, the product ash content greatly improved to $8.29 \%, 7.74 \%$ and $10.9 \%$.

\subsubsection{Kinetic Studies}

The influence of Al-PAM on fine coal flotation can be partially explained by the flotation rate constants. Batch flotation in a mechanical cell is based on the first-order flotation rate Equation (3) [22].

$$
\frac{\mathrm{d} C}{\mathrm{~d} t}=-k C(t)
$$

where $C$ is the concentration of hydrophobic particles in the cell at any time, $t$ is time (representing the duration of the flotation test) and $k$ is the flotation rate constant. Solving Equation (3) for the flotation rate constant results in Equation (4):

$$
k=-\left(\frac{1}{t}\right) \ln (1-R)
$$

where $R$ is the flotation recovery, which is defined as the ratio of the concentration of hydrophobic particles at time $t(C(t))$ to the original concentration of hydrophobic particles $\left(C_{0}\right)$. The data collected from the experiments were then used to estimate rate constant values, enabling the better evaluation of the flotation performance with or without Al-PAM. Kinetic rates were conducted at a slightly acidic pH of 5 and at neutral $\mathrm{pH}$. The flotation recovery as a function of time in the presence and absence of $\mathrm{Al}-\mathrm{PAM}$ at pH 5 and 7.8 is shown in Figure 10. The tests results showed that flotation in the presence of Al-PAM at a slightly acidic $\mathrm{pH}$ of 5 had a considerably higher combustible recovery within a shorter timeframe than in the absence of Al-PAM. At a natural $\mathrm{pH}$ of 7.8, the presence of Al-PAM resulted in a higher recovery than in the absence of Al-PAM. The calculated rate constants values for the various examined cases are summarized in Table 3.

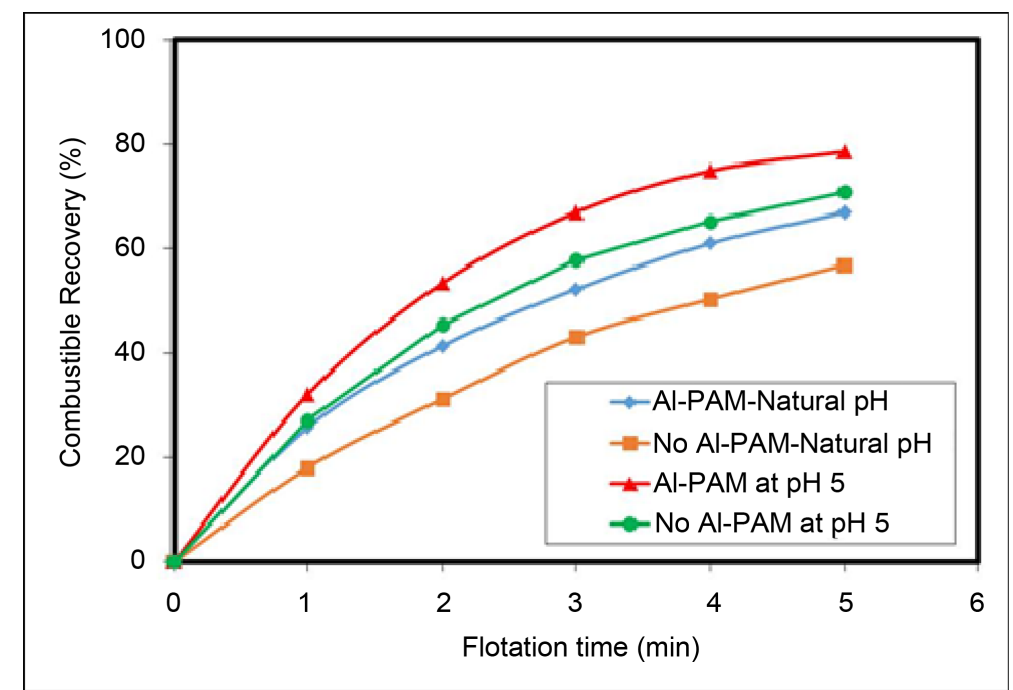

Figure 10. Kinetic rate tests with and without Al-PAM at natural $\mathrm{pH}$ of 7.8 and $\mathrm{pH} 5$. 


\subsection{Comparative Studies}

\subsubsection{Influence of Polyacrylamide Polymer (PAM)}

For comparison, coal flotation experiments were conducted in the presence of commercially available polyacrylamide (with a molecular weight of $\sim 5 \times 10^{6}$ Dalton) to determine the effects of polyacrylamide on combustible recovery and product ash. Flotation experiments were first conducted by varying the dosage of PAM at a constant natural $\mathrm{pH}$ of 7.8. The effects of PAM on the combustible recovery of coal and product ash at $\mathrm{pH} 7.8$ as a function of PAM dosage are shown in Figure 11. Without PAM in the flotation pulp (only collector and frothing agents were present), the combustible recovery of the coal was $59.47 \%$ with a product ash content of $8.2 \%$. However, the recovery of coal decreased when PAM was added to the flotation and as the PAM dosage increased from 0.08 to $3 \mathrm{mg} / \mathrm{L}$. The overall combustible recovery of coal decreased from $54.47 \%$ to $30.54 \%$.

The results obtained in this study correlated with those obtained by Moudgil [4]. Moudgil conducted coal flotation experiments in the presence of PAM and found that coal recovery completely ceased after the addition of PAM due to the adsorption of hydrophilic polymer molecules on coal particles, rendering the surface of the coal particles polar. These results could explain the observations of this study. The addition of

Table 3. Flotation rate constants and ultimate recovery.

\begin{tabular}{ccc}
\hline & Al-PAM Present & No Al-PAM \\
\hline Parameter 1: $\mathbf{k}($ min-1) & & \\
\hline pH 5 & 0.36 & 0.28 \\
pH 7.8 & 0.25 & 0.18 \\
\hline Parameter 2: R(\%) & & 70.5 \\
\hline pH 5 & 78.5 & 59.4 \\
\hline pH 7.8 & 68 &
\end{tabular}

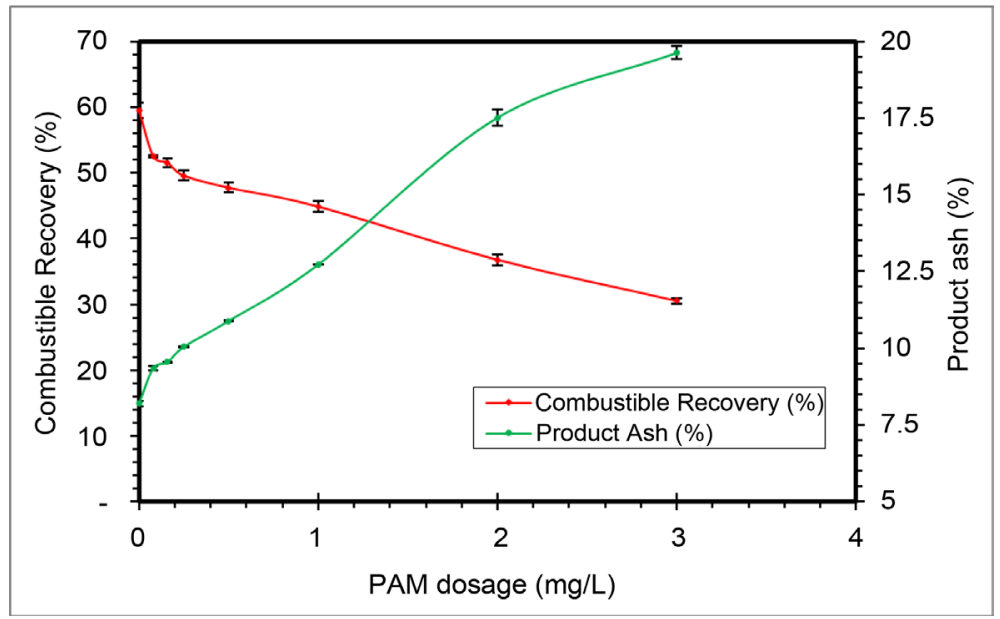

Figure 11. Effects of organic polyacrylamide (PAM) dosage on the combustible recovery (\%) of coal and product ash (\%). 
PAM increased the amount of ash content in the concentrate. The product ash obtained when no PAM was added was lower at an ash content of $8.2 \%$. However, the ash content in the concentrate increased considerably when PAM was added to the flotation pulp. The overall ash content in the product ash increased from $8.2 \%$ to $19.62 \%$.

\subsubsection{Influence of a Dispersant}

Coal flotation was conducted in the presence of an ash dispersant to investigate whether an ash dispersant would optimize the flotation performance. Sodium metasilicate was selected as the dispersant because it has been reported to be one of the most effective dispersants for coal flotation [12]. A control experiment (with no dispersant added) was performed for baseline measurements. The combustible recovery of coal and product ash for the control experiment was $59.58 \%$ and $8.2 \%$, respectively. As shown in Figure 12, the addition of the sodium metasilicate dispersant in the range of 0.2 to 0.8 $\mathrm{mg} / \mathrm{L}$ improved the overall combustible recovery of coal from $59.58 \%$ to $63.80 \%$ and increased the product ash content from $8.2 \%$ to $8.1 \%$. Therefore, a dosage of sodium metasilicate of 0.2 to $0.8 \mathrm{mg} / \mathrm{L}$ could ably disperse clay slimes and eliminate slime coating. This would prevent the floating of high ash-forming particles. Bulatovic et al. proposed that sodium metasilicate disperses clay slimes by two mechanisms [23]. One mechanism involves the dispersion of clay particles by electrostatic repulsion due to the presence of free polysilic acid, which is partially ionized. The adsorption of these ions on the surface of clay particles increases the negative charge density and thereby results in particle repulsion. The other mechanism is that sodium metasilicate may adsorb onto the clay particle surface and form a hydrated layer, leading to an increased negative charge and electrostatic repulsion [24]. The increased combustible recovery of coal in the presence of the dispersant alone was smaller when compared with the case where flotation was carried out using Al-PAM alone. The addition of Al-PAM to the flotation pulp increased the combustible recovery of coal by $7.2 \%$, whereas the dispersant increased the recovery by $4 \%$.

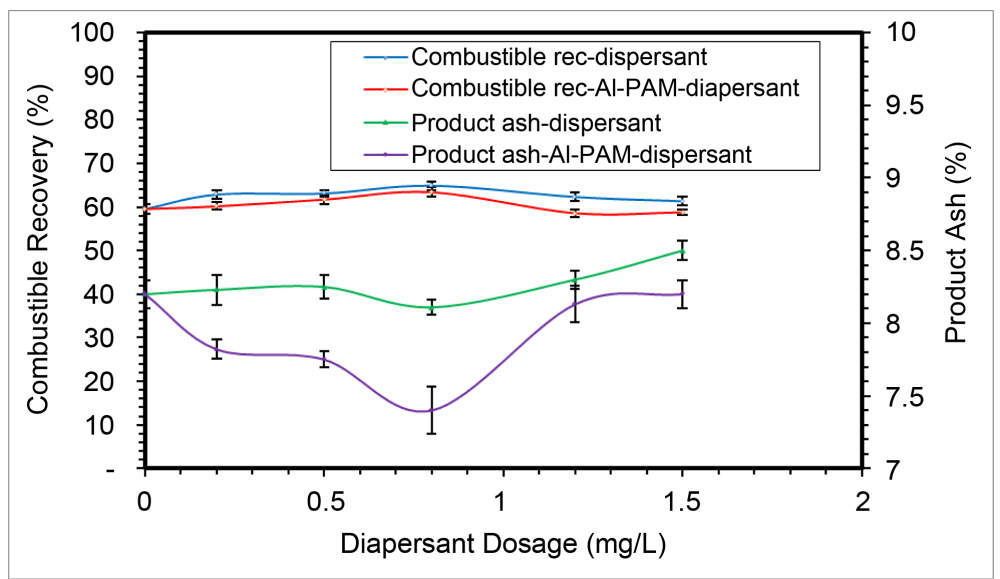

Figure 12. Influence of dispersant dosage (in the absence of Al-PAM) and dual use of the Al-PAM-dispersant system on the combustible recovery (\%) of coal and product ash (\%). 
When the sodium metasilicate dispersant dosage increased from 1.2 to $1.5 \mathrm{mg} / \mathrm{L}$, the combustible recovery of coal decreased but the product ash content increased. These findings were not surprising because the limited literature on fine coal flotation in the presence of sodium metasilicate has largely indicated that moderate to high levels of coal depression could be expected when sodium metasilicate is added in excess. However, more recent studies have shown that the depression of coal during flotation in the presence of sodium metasilicate could be minimized by adding relatively low dosages of dispersing agents. In this study, the product ash was slightly contaminated in the presence of sodium metasilicate. Similar results have been reported in the literature. Zolghadri et al. concluded that froth contamination was likely because the dispersion of coagulates consisted of higher levels of non-hydrophobic ash particles and lower levels of hydrophobic ash particles [24]. Higher amounts of ash particles could be entrained in the froth bubbles due to the lower concentrations of hydrophobic ash parts on coagulates. The optimum dosage of dispersants providing for the highest combustible recovery of coal $(63.80 \%)$ was $0.8 \mathrm{mg} / \mathrm{L}$.

\subsection{Synergetic Studies}

Experiments were conducted to evaluate the use of a dual Al-PAM-dispersant system to improve the combustible recovery of coal and ash depression during coal flotation. First, floatation experiments were conducted using Al-PAM alone at various dosages. These experiments were mainly conducted to determine the optimum dosage of Al-PAM, as shown in Figure 4. Then, flotation experiments were conducted at the optimum dosage Al-PAM with varying dosages of sodium metasilicate dispersant. The Al-PAM dosage was kept constant at $0.25 \mathrm{mg} / \mathrm{L}$ throughout the experiments. In each experiment, the dispersant, collector, Al-PAM and frothing agents were added sequentially.

As shown in Figure 12, the overall combustible recovery of coal was improved using the dual Al-PAM-dispersant system. The combustible recovery of coal increased to $63.80 \%$ at sodium metasilicate dosages between 0.2 and $0.8 \mathrm{mg} / \mathrm{L}$. A slight decrease was observed in the coal recovery when the dual polymer-dispersant system was used compared with polymer alone. This depression may be due to the adsorption of sodium metasilicate on the surface of the coal particles, imparting hydrophilicity, prior to polymer addition. However, unlike combustible recovery, the overall product ash was greatly improved when the dual Al-PAM-dispersant system was used compared with the use of dispersant or Al-PAM alone. A product ash with an improved ash content of 7.4\% was obtained when the dual Al-PAM-dispersant system was used when compared with the ash content of $8.11 \%$ observed for a system using dispersant alone. When sodium metasilicate was added to the suspension prior to adding Al-PAM, the silicate dissociates to produce highly electronegative anionic species, which then electrostatically adsorb onto the ash-forming minerals (and to a lesser extent, on coal particles) and causes the charge density in an electric double layer around the coal and ash-forming mineral particles to increase. This results in increased electrical repulsion 
and thereby disperses the coal and ash-forming mineral particles in the suspension. The dispersion effect of sodium metasilicate allows Al-PAM to easily adsorb on the surface of high-ash-forming minerals (slimes), facilitates their aggregation and decreases the entrainment of ash particles in the froth layer.

To further investigate the dual use of the Al-PAM-dispersant system, flotation experiments were conducted at a slightly acidic $\mathrm{pH}$ of 5 and an alkaline $\mathrm{pH}$ of 10 . In this set of experiments, the polymer dosage, dispersant dosage, impeller speed and polymer conditioning time were kept constant at $0.25 \mathrm{mg} / \mathrm{L}, 0.8 \mathrm{mg} / \mathrm{L}, 1800 \mathrm{rpm}$ and $6 \mathrm{~min}$, respectively. Figure 13(a) and Figure 13(b) show the effect of $\mathrm{pH}$ on the clean coal combustible recovery and product ash in the presence of dispersant alone or with the dual Al-PAM-dispersant system. As seen from Figure 13(a), the use of dispersant or the dual use of the Al-PAM-dispersant system did not improve the combustible recovery of coal at $\mathrm{pH} 5$ or 10 . The observed decrease in the combustible recovery at the acidic $\mathrm{pH}$ was due to better ability of sodium metasilicate to dissociate to form colloidal silica gels. These colloidal silica gels are negatively charged at acidic $\mathrm{pH}$ and will readily adsorb onto the positively charged coal surfaces, rendering them hydrophilic and allowing for high-ash-forming minerals to float. These results correspond well with the results reported in the literature [25]. As shown in Figure 13(b), higher product ash content was obtained when a dispersant was used alone at either $\mathrm{pH}$. However, a cleaner product ash of 7.4\% was obtained when a dual Al-PAM-dispersant system was used at $\mathrm{pH} 7.8$.

\subsection{Electrokinetic Studies}

The role of Al-PAM in fine coal flotation was fundamentally explored by examining the surface properties of raw coal and froth after polymer-assisted flotation. Zeta potential measurements were conducted for clean coal (4\% ash), raw coal and concentrates from froth flotation experiments in the absence or presence of Al-PAM. Froth products obtained from the use of the dual Al-PAM-dispersant system were also tested for comparison. The zeta potential values of clean coal (4\% ash) and raw coal as functions of increasing and decreasing $\mathrm{pH}$ were determined and are shown in Figure 14. Clean coal
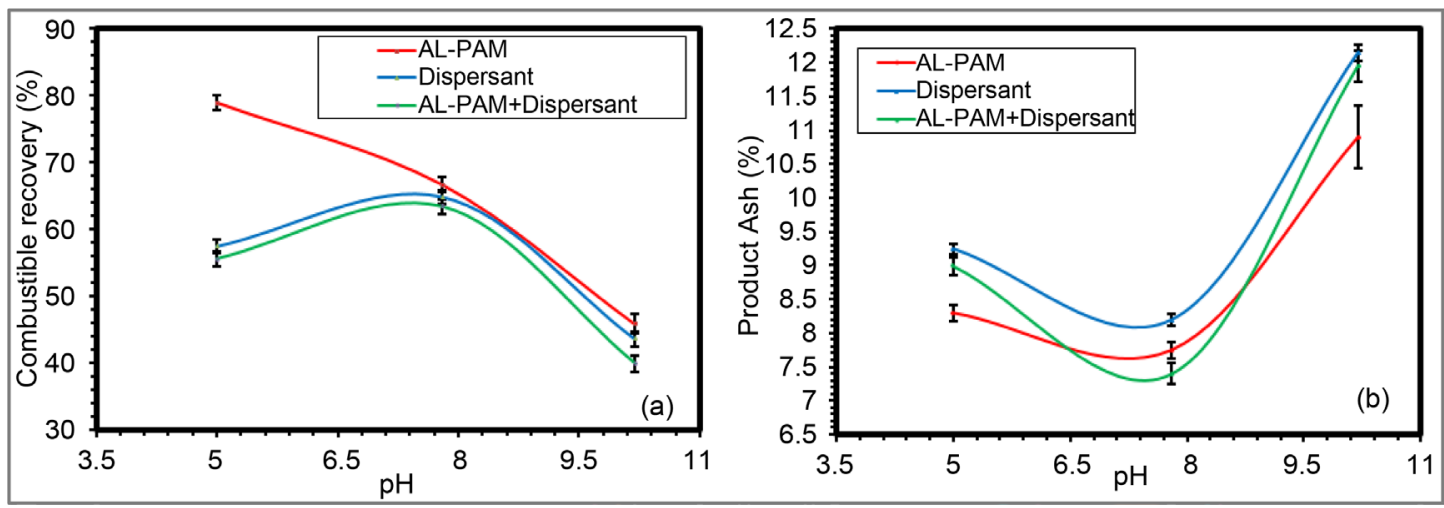

Figure 13. Effect of $\mathrm{pH}$ on combustible recovery (a) and product ash (b) in the presence of Al-PAM, dispersant and a dual Al-PAM-dispersant system. 


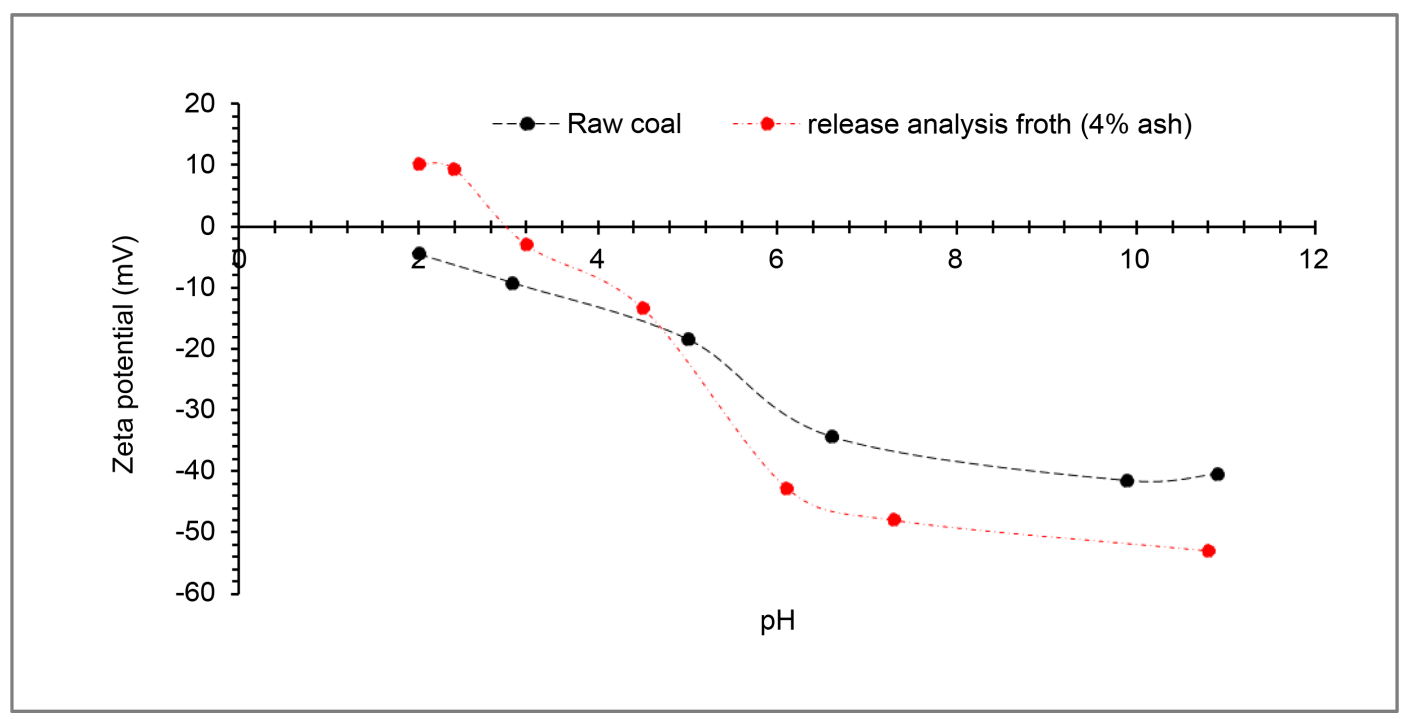

Figure 14. Zeta potential vs. $\mathrm{pH}$ curve for clean coal (4\% ash) and raw coal.

( $4 \%$ ash) exhibited a positive charge at $\mathrm{pH}$ levels below 3, whereas raw coal has a negative charge over the $\mathrm{pH}$ range of 2 - 11. As the $\mathrm{pH}$ increased from 3 to 11, the zeta potential of clean coal ( $4 \%$ ash) became more negative. The isoelectric point of clean coal is approximately $\mathrm{pH} 3.5$, which indicates that as $\mathrm{pH}$ decreased below 3 , the amount of adsorbed hydronium $\left(\mathrm{H}^{+}\right)$ions increased on the surface of the coal, positively charging the surface of the coal. Conversely, when the $\mathrm{pH}$ increased above 3, the amount of hydroxyl $\left(\mathrm{OH}^{-}\right)$ions increased and adsorbed on the surface of the coal particles, replacing the hydronium ions and rendering the surface negatively charged. This indicates that changing the concentration of the hydronium or hydroxyl ions changes the magnitude and sign of the zeta potential. As the $\mathrm{pH}$ increased from 2 to 11 , the zeta potential of the clean coal ( $4 \%$ ash) was the most negative, whereas that of the raw coal was the least negative. The less negative surface charge of raw coal (compared with clean coal) under increasing $\mathrm{pH}$ is attributed to the adsorption of positively charged metal ions, such as $\mathrm{Mg}^{2+}, \mathrm{Ca}^{2+}$ and $\mathrm{Fe}^{2+}$, on the negatively charged surface of raw coal particles [26].

Results for the zeta potential distribution peaks for clean coal, raw coal, concentrates obtained from froth flotation experiments using Al-PAM, the dual Al-PAM-dispersant system and collector or frothing agent alone are shown in Figure 9. The zeta potential distribution peaks for clean coal, raw coal and froth concentrate obtained from Al-PAM, the dual Al-PAM-dispersant system and collector or frothing agent alone were $-3.5,-46.59,-21.5-10.04$ and -32.9 , respectively. The shift of the peaks to more positive zeta potential values after flotation indicates a significant removal of ash-forming minerals from the coal surface by Al-PAM. For illustrative purposes, the interaction between ash-forming mineral and coal is shown in Figure 9 by black and white circles representing mineral matter (slime coating) and coal particles, respectively. For raw coal, coal particles are fully covered by the ash-forming minerals (slime coating), as shown schematically in the figure inset. This was confirmed by the measured zeta potential of raw coal. The zeta potential peak shifted left (more negative) and 
is dependent on the ratio of the components, illustrating the reduced combustible recovery of coal in flotation experiments.

\section{Conclusion}

The laboratory batch flotation results obtained in this study demonstrated the positive impacts of hybrid polyacrylamide polymers (Al-PAMs) on the combustible recovery of coal and ash reduction. Results indicate that the use of a dual Al-PAM-dispersant system provided an attractive means for improving the overall flotation performance. An optimal separation was obtained when $0.25 \mathrm{mg} / \mathrm{L}$ of Al-PAM and $0.8 \mathrm{mg} / \mathrm{L}$ of sodium metasilicate were added to the flotation pulp. The study also shows that the depression of coal during flotation in the presence of sodium metasilicate can be minimized by adding relatively low dosages of dispersing agents. However, moderate-to-high levels of coal depression may be expected when sodium metasilicate is added in excess. Furthermore, this work demonstrates that an organic/inorganic (hybrid) polyacrylamide polymer is a better ash-forming depressant than commercially available organic polyacrylamide (PAM).

\section{Acknowledgements}

The authors would like to thank Dr. Mary R. Reidmeyer and Dr. Ronald J. OMalley from the department of Materials Science and Engineering at Missouri University of Science and Technology for allowing the use of mineral processing facilities.

\section{References}

[1] Seifelnassr, A.A.S. (2004) Wetting Prpoerties of an Egyptian Coal and Their Relation to Its Flotation Behaivor. Proceedings of the 6th International Mineral Processing Sympsium, Kusadi, 24-26 September 2004, 209-213.

[2] Committee on Coal Waste, Committee on Earth Resources, Board on Earth Sciences and Resources, Division on Earth and Life Studies and National Research Council (2002) Coal Waste Impoundments. National Academy Press, Washington DC.

[3] Yoon, R.-H. and Aksoy, B.S. (1999) Hydrophobic Forces in Thin Water Films Stabilized by Dedecylammonium Chloride. Journal of Colloid Science, 211, 1-10. https:/doi.org/10.1006/jcis.1998.5961

[4] Moudgil, B.M. (1983) Effect of Polyacrylamide and Polyethylene Oxide Polymers on Coal Flotation. Colloids and Surfaces, 8, 225-228. https:/doi.org/10.1016/0166-6622(83)80086-9

[5] Pawlik, M. (2005) Polymeric Dispersants for Coal-Water Slurries. Colloids and Surfaces A: Physicochemical and Engineering Aspects, 266, 82-90. https:/doi.org/10.1016/j.colsurfa.2005.04.043

[6] Fedorova, A.M. (1958) Testing of New Flotation Reagents, Obogashchenie i Briket. Uglei Moscow Gos. Nauch.-Tekh. Izd. Lit. Ugol. Prom., 7, 38-45.

[7] Ofori, P., O’Brien, G., Firth, B. and McNally, C. (2012) The Use of Tri-Block Copolymer Surfactants as Promoters to Improve Flotation Recovery of Poorly Floating Coal Components. International Journal of Coal Preparation and Utilization, 32, 103-119. https:/doi.org/10.1080/19392699.2011.640298

[8] Parekh, B.K. and Chen, Z. (2004) Recovery of Clean Coal from Polymer Flocculated Raw 
Coal Slurry. Minerals and Metallurgical Processing, 266, 214-216.

[9] Tao, D.P., Lu, M.X., Richardson, P.E., Luttrell, G.H., Adel, G.T. and Yoon, R. (1994) Enhanced Pyrite Rejection in Coal Flotation. Annual International Pittsburgh Coal Conference: Coal, Energy and the Environment, Pittsburgh, 12-16 September 1994, 891-896.

[10] Chander, S. (1996) Mechanism of Coal Flotation by Insoluble Collectors in the Presence of PEO/PPO Triblock Co-Polymers. Changing Scopes in Mineral Processing. Proceeding of the 6th International Mineral Processing Symposium. Kusadasi, 24-26 September 1996, Rotterdam, 461-467.

[11] Reza, M. (2007) Reduction of Sulfur and Ash from Tabas Coal by Froth Flotation. Iranian Journal of Chemistry \& Chemical Engineering, 26, 35-40.

[12] Raleigh, C.E. and Aplan, F.F. (1983) The Use of Mineral Matter Dispersants and Depressants during the Flotation of Bituminous Coals. Coal Science and Technology, 21, 71-90. https:/doi.org/10.1016/B978-0-444-81476-0.50014-4

[13] Li, H., Long, J., Xu, Z. and Masliyah, J.H. (2008) Novel Polymer Aids for Low-Grade Oil Sand Ore Processing. Canadian Journal of Chemical Engineering, 86, 168-176. https:/doi.org/10.1002/cjce.20030

[14] Alagha, L., Wang, S., Xu, Z. and Masliyah, J. (2011) Adsorption Kinetics of a Novel Organic-Inorganic Hybrid Polymer on Silica and Alumina Studied by Quartz Crystal Microbalance. The Journal of Physical Chemistry C, 115, 15390-15402. https:/doi.org/10.1021/jp202563q

[15] Matsunami, H., Fujita, C., Ogawa, K. and Kokufuta, E. (2007) Static Light Scattering Study of Complex Formation between Protein and Neutral Water-Soluble Polymer. Colloids and Surfaces B: Biointerfaces, 56, 149-154. https:/doi.org/10.1016/j.colsurfb.2006.10.011

[16] Mattison, K. and Kaszuba, M. (2003) Measuring Absolute Protein Molecular Weight: Is Multi-Angle Instrumentation Absolutely Essential? American Biotechnology Laboratory, 21, 28-31.

[17] Dell, C. (1964) An Improved Release Analysis Procedure for Determining Coal Washability. Journal of Institute of Fuel, 37, 149-150.

[18] AST Mstandards (2012) Standard Test Method for Ash in the Analysis Sample of Coal and Coke from Coal.1-6.

[19] Kalyani, V.K. and Gouricharan, T. (2005) Effect of Conditioning on the Beneficiation of Dilute Coking Coal Fines by Froth Flotation. The European Journal of Mineral Processing and Environmental Protection, 5, 72-77.

[20] Van Le, H. (1977) Floatability of Coal and Pyrite. US Energy Research and Development Administration, Ames.

[21] Somasundaran, P., Roberts, C. and Ramesh, R. (1991) Effects of Oxidizing Methods on the Flotation of Coal. Minerals Engineering, 4, 43-48. https:/doi.org/10.1016/0892-6875(91)90117-E

[22] Laskowski, J.S. (2001) Developments in Mineral Processing: Coal Flotation and Fine Coal Utilization. Vol. 14, Elsevier, Amsterdam.

[23] Bulatovic, S. (2007) Handbook of Flotation Reagents: Chemistry, Theory and Practice, Volume 1: Flotation of Sulfide Ores. Elsevier, Amsterdam.

[24] Zolghadri, M., Ghaffari, A., Amiri Parian, M. and Haghi, H. (2012) Interaction between MIBC and Sodium Metasilicate in Flotation of Coal Slimes. 26th International Mineral Processing Congress (IMPC), New Delhi, 24-28 September 2012, 06258-06264.

[25] Fuerstenau, D.W. (1968) Mechanism of Soluble Salt Flotation, Part. I. Transactions AIME, 
241, 56-64.

[26] Liu, D., Somasundaran, P., Vasudevan, T.V. and Harris, C.C. (1994) Role of pH and Dissolved Mineral Species in Pittsburgh No. 8 Coal Flotation System-I. Floatability of Coal. International Journal of Mineral Processing, 41, 201-214.

https:/doi.org/10.1016/0301-7516(94)90028-0

\section{Submit or recommend next manuscript to SCIRP and we will provide best service} for you:

Accepting pre-submission inquiries through Email, Facebook, LinkedIn, Twitter, etc. A wide selection of journals (inclusive of 9 subjects, more than 200 journals)

Providing 24-hour high-quality service

User-friendly online submission system

Fair and swift peer-review system

Efficient typesetting and proofreading procedure

Display of the result of downloads and visits, as well as the number of cited articles

Maximum dissemination of your research work

Submit your manuscript at: http://papersubmission.scirp.org/

Or contact ijcce@scirp.org 